\title{
Cu-Pd Dual Catalyst System for Amide Styrylation Reaction from Potassium Styryltrifluoroborates and Amides
}

\author{
Mohammad Al-Masum*, Mohammed Shahidul Islam, Wejdan Shaban \\ Department of Chemistry, Tennessee State University, Nashville, TN, USA \\ Email: ${ }^{*}$ malmasum@tnstate.edu
}

How to cite this paper: Al-Masum, M., Islam, M.S. and Shaban, W. (2017) Cu-Pd Dual Catalyst System for Amide Styrylation Reaction from Potassium Styryltrifluoroborates and Amides. International Journal of Organic Chemistry, 7, 254-262.

https://doi.org/10.4236/ijoc.2017.73019

Received: June 30, 2017

Accepted: August 8, 2017

Published: August 11, 2017

Copyright $\odot 2017$ by authors and Scientific Research Publishing Inc. This work is licensed under the Creative Commons Attribution International License (CC BY 4.0).

http://creativecommons.org/licenses/by/4.0/

\begin{abstract}
An interesting reaction procedure for the cross-coupling of potassium styryltrifluoroborates and amides has been developed by using $\mathrm{PdCl}_{2}\left(\mathrm{~d}^{\mathrm{t}} \mathrm{bpf}\right)-\mathrm{CuI}$ dual catalyst system. By applying this method, good numbers of amide styrylation products are formed in $85 \%$ - $92 \%$ yields.
\end{abstract}

\section{Keywords}

Amide Styrylation Reaction, Dual Catalyst, Microwave

\section{Introduction}

Nitrogen containing compounds are important because of their presence in natural products, their presence in synthetic organic products, and they display wide-range of functionalities. The formation of the $\mathrm{C}-\mathrm{N}$ bond is important as it opens avenues for introducing nitrogen in organic molecules. Buchwald and Hartwig have separately developed successful metal complexes and ligands for the construction of C-N bonds using transition metal-catalyst [1]-[7]. Although significant progress has occurred in this field, the formation of $\mathrm{C}-\mathrm{N}$ bond through amide styrylation reaction has not been animated by many chemists. The pioneering work by Buchwald's group on palladium-catalyzed intermolecular amidation of aryl halides and effective use of Xantphos as ligand is promising [8]. In another development, Buchwald showed the copper-catalyzed amidation of vinyl halides and the effective use of $\mathrm{N}, \mathrm{N}$-dimethyl ethylene diamine ligand [9]. Hartwig also reported the ligand effect of $\mathrm{P}\left({ }^{\mathrm{t}} \mathrm{Bu}\right)_{3}$ and Pd-catalyzed intermolecular cross-coupling of aryl bromides and chlorides with tert-butyl carbamate [10]. Other groups also reported palladium-catalyzed amide arylation reactions 
[11] [12] [13]. In our ongoing process in making C-N bond formation reactions by cross-coupling of styryltrifluoroborates and sodium nitrite as well as from aryltrifluoroborates and bismuth nitrate [14] [15] [16], we tried to explore amide styrylation reaction by introducing potassium styryltrifluoroborates and various amides. In this work, we have originated copper-palladium dual catalyst system for the successful amide styrylation reaction between styryltrifluoroborates and amides (Scheme 1).

\section{Results and Discussion}

Various aromatic and aliphatic amides were used as N-H source because of the tendency of $\mathrm{N}-\mathrm{H}$ bond to leave proton due to the electronegativity difference between nitrogen and hydrogen. We employed many palladium complexes as catalysts and solvent system in single catalyst method to find an effective catalyst system. Also, various ratios of amides and potassium styryltrifluoroborates were applied while the base system and number of bases were varied simultaneously. Due to the encouraging catalytic effect of $\mathrm{PdCl}_{2}\left(\mathrm{~d}^{\mathrm{t}} \mathrm{bpf}\right)$ complex in cross-coupling reaction, we concentrated on dppf coordinated palladium complexes for amide styrylation along with other palladium complexes. None of them worked amidation, but the dppf complexes showed the formation of aldol type products from amides instead of new C-N bonded amide styrylation product. Some of the aldol type observations are shown in (Figure 1). Formations of aldol product were observed in GC-MS and NMR analysis (Scheme 2).

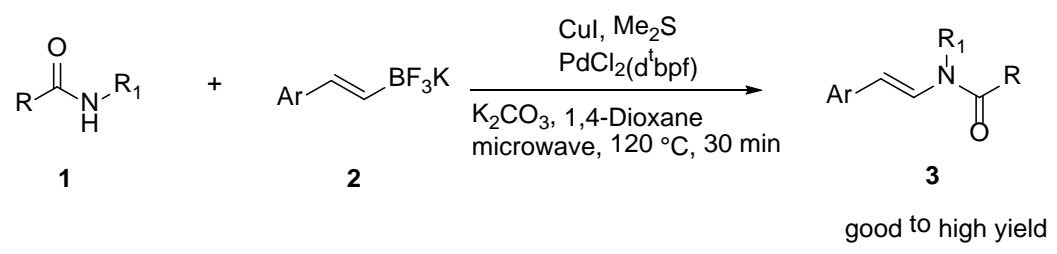

Scheme 1. Cu-Pd dual catalyst system for amide styrylation reaction.

\begin{tabular}{|c|c|c|c|c|}
\hline Solvents & Catalyst & Base & Temperature & ss-coupling \\
\hline THF- $\mathrm{H}_{2} \mathrm{O}$ & $\mathrm{PdCl}_{2}$ (dppf) $\mathrm{CH}_{2} \mathrm{Cl}_{2}$ & $\mathrm{~K}_{2} \mathrm{CO}_{3}$ & $120^{\circ} \mathrm{C}$ & None \\
\hline 'PrOH- $\mathrm{H}_{2} \mathrm{O}$ & $\begin{array}{l}\mathrm{Pd}(\mathrm{dba})_{3} \mathrm{CHCl}_{3} I \\
\mathrm{dppf}\end{array}$ & $\mathrm{K}_{2} \mathrm{CO}_{3}$ & $140^{\circ} \mathrm{C}$ & None \\
\hline 'PrOH- $\mathrm{H}_{2} \mathrm{O}$ & $\mathrm{PdCl}_{2}\left(\mathrm{~d}^{\mathrm{t}} \mathrm{ppf}\right)$ & $\mathrm{NaO}^{t} \mathrm{Bu}$ & $100^{\circ} \mathrm{C}$ & None \\
\hline Toluene & $\begin{array}{l}\mathrm{PdCl}_{2} \text { (dppf). } \\
\mathrm{CH}_{2} \mathrm{Cl}_{2}\end{array}$ & $\mathrm{NaO}{ }^{t} \mathrm{Bu}$ & $120^{\circ} \mathrm{C}$ & None \\
\hline 1,4-Dioxane & $\begin{array}{l}\mathrm{Pd}(\mathrm{OAc})_{2} I \\
\mathrm{dppf}\end{array}$ & Hunig's Base & e $140^{\circ} \mathrm{C}$ & None \\
\hline Toluene & $\begin{array}{l}\mathrm{Pd}(\mathrm{OAc})_{2} I \\
\text { Xantphos }\end{array}$ & $\mathrm{NaO}^{t} \mathrm{Bu}$ & $120^{\circ} \mathrm{C}$ & None \\
\hline 1,4-Dioxane & $\mathrm{PdCl}_{2}\left(\mathrm{~d}^{\mathrm{t}} \mathrm{ppf}\right)$ & $\mathrm{NaO}^{t} \mathrm{Bu}$ & $140^{\circ} \mathrm{C}$ & None \\
\hline 1,4-Dioxane & $\mathrm{PdCl}_{2}\left(\mathrm{~d}^{\mathrm{t}} \mathrm{ppf}\right)$ & $\mathrm{K}_{2} \mathrm{CO}_{3}$ & $140^{\circ} \mathrm{C}$ & None \\
\hline
\end{tabular}

Figure 1. Some examples of single catalyst method for amide styrylation. 
<smiles>CC(=O)Nc1ccc(C)cc1</smiles><smiles>CC(=O)N(c1ccc(C)cc1)C(C)(O)Nc1ccc(C)cc1</smiles><smiles>CC(=O)Nc1ccccc1</smiles><smiles>[CH2-]C</smiles><smiles>CC(=O)N(c1ccccc1)C(C)(O)Nc1ccccc1</smiles>

Scheme 2. Aldol type product.

In the course of these studies, we struggled to establish single catalyst system for amide styrylation reaction, consequently we screened dual catalyst system [17]. The palladium chloride complex $\left[\mathrm{PdCl}_{2}\left(\mathrm{~d}^{\mathrm{t} b p f}\right)\right]$ is a useful palladium complexes which has been successfully applied as a catalyst in recent years in various organic transformations involving potassium organotrifluoroborates [18] [19] [20] [21]. The higher bite angle of P-Pd-P in $\mathrm{PdCl}_{2}\left(\mathrm{~d}^{t} \mathrm{bpf}\right)$ improves its effectiveness to be used as catalyst [22] [23] [24]. Among other available complexes, this palladium complex illustrates better catalytic effect for C-N bond formation with styryltrifluoroborates. Copper iodide is another catalyst we chose for our dual catalyst system because of its low cost and effective catalytic activity on cross-coupling. The $\mathrm{N}-\mathrm{H}$ bond of amide first activated with $\mathrm{Cu}$-catalyst to form $\mathrm{Cu}$-species and $\mathrm{C}-\mathrm{BF}_{3} \mathrm{~K}$ bond of styryltrifluoroborates activated separately with $\mathrm{Pd}$-catalyst to get $\mathrm{Pd}$-species in the presence of a proper amount of solvent and base. Then $\mathrm{Cu}$-species was transferred into $\mathrm{Pd}$-species and the resulting mixture was microwaved $(300 \mathrm{~W})$ at $120^{\circ} \mathrm{C}$ for 30 minutes. The successful results for this new process for amide styrylation reaction are summarized in Figure 2.

The solid product was isolated in good yields. This isolated product was pure enough to use for analysis without further purification. The cross-coupled conjugated amide products with new $\mathrm{C}-\mathrm{N}$ bond seemed to be very reactive. When the reaction products were subjected to silica gel chromatography for purification TLC and NMR clearly showed decomposition. Even when the reaction product was subjected to neutral alumina chromatography instead of silica gel, no significant improvement for the product purification was observed. In two cases (Figure 2, Entries 7, 8), we were able to collect products by column chromato 


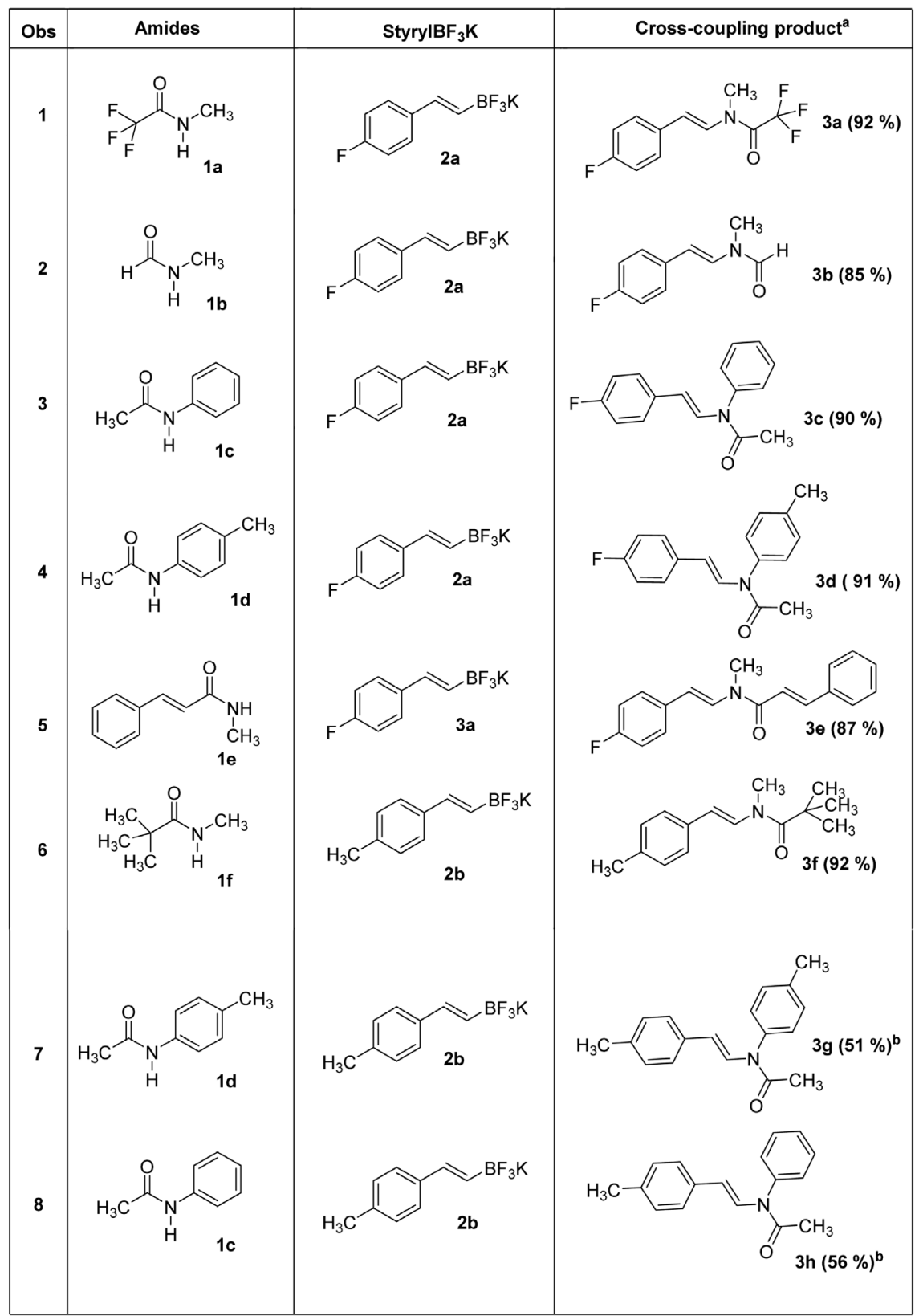

Figure 2. Cu-dual catalyst system for amide styrylation reaction ${ }^{\mathrm{a}}$. ${ }^{\text {The }}$ The reaction products were collected after filtered through celite pad twice and dried under vacou over night Column Chromatography attempts were unsuccessful. ${ }^{\mathrm{b}}$ The products $3 \mathrm{~g}$ and $\mathbf{3 h}$ are separated by silica get chromatography.

graphy but yields reduced significantly. A combined NMR study of ${ }^{1} \mathrm{H} N M R,{ }^{13} \mathrm{C}$ $\mathrm{NMR}$, and ${ }^{19} \mathrm{~F}$ NMR confirmed the formation of new C-N bonded crosscoupled amides. A series of reactions were run by using various potassium styryltrifluoroborates and amides as an $\mathrm{N}-\mathrm{H}$ source. Figure 2 shows the successful series of amide styrylation reaction products from amides and styryltrifluoroborates.

In ${ }^{1} \mathrm{H}$ NMR of product $3 \mathrm{a}, \delta$ value $\mathrm{H}_{\mathrm{a}}$ and $\mathrm{H}_{\mathrm{b}}$ are $7.37 \mathrm{ppm}$ and $6.19 \mathrm{ppm}$ re- 
spectively but in starting material of 4-fluoro-styryltrifluoroborates, these peaks show at 6.20 and $6.15 \mathrm{ppm}$. The chemical shift to downfield is an indication that carbon attached to $\mathrm{H}_{\mathrm{a}}$ now bonded with more electronegative nitrogen. Also, the ${ }^{19} \mathrm{~F}$ NMR of product $3 \mathrm{a}$ confirmed the presence of 2 (two) fluorine peak (-76.4 ppm for $\mathrm{CF}_{3}$ and -114.9 ppm for p- $-\mathrm{F}_{6} \mathrm{H}_{4}-$ ). In starting material of 4-fluorostyryltrifluoroborates, $\mathrm{p}-\mathrm{F}-\mathrm{C}_{6} \mathrm{H}_{4}$-appears at -119.5 and $\mathrm{BF}_{3} \mathrm{~K}$ at $-141.8 \mathrm{ppm}$. [In case of $\mathrm{p}-\mathrm{F}-\mathrm{C}_{6} \mathrm{H}_{4}-\mathrm{BF}_{3} \mathrm{~K}$, Reported ${ }^{19} \mathrm{~F}$ (data are -118.6 and -139.1 by Molander group) [25] [26] Little variation in ppm may be the effect of solvents and styryl moiety.]

Amide styrylation reaction via cross-coupling of potassium styryltrifluoroborates with amides is a new addition to Buchwald's amide arylation reaction from aryl halides and amides. The probable reaction mechanism of this reaction is shown in Scheme 3.

Our research employs microwave irradiation to underpin N-H activation of amides and cross-coupling with potassium styryltrifluoroborates forming enamides which are building blocks of a vast range of industrial pharmaceuticals, intermediates, agrochemicals, and biological functionalities. This work also demonstrates a novel application of dual catalyst system of $\mathrm{PdCl}_{2}\left(\mathrm{~d}^{\mathrm{t}} \mathrm{bpf}\right)$ and $\mathrm{CuI}$ for effective cross-coupling of styryltrifluoroborates and amides.<smiles>[R7]NC([R])=O</smiles>

$100 \mathrm{~mol} \%$ Cul, $\mathrm{K}_{2} \mathrm{CO}_{3} 2$ eq., $\mathrm{Me}_{2} \mathrm{~S} 0.5 \mathrm{ml}$ 1,4-Dioxane $2 \mathrm{ml}, 30 \mathrm{~min} \mathrm{rt}$<smiles></smiles>

$2 \mathrm{~mol} \% \mathrm{PdCl}_{2}\left(\mathrm{~d}^{\mathrm{t}} \mathrm{bpf}\right)$ $\mathrm{K}_{2} \mathrm{CO}_{3} 2$ eq., 1,4-Dioxane $2 \mathrm{ml}, 30 \mathrm{~min}$ rt<smiles>[R]C(=O)N([R])Cl</smiles>

Flask 2<smiles>CCCCCCCCC=Cc1ccc(F)cc1</smiles>

Flask 1

$M W, 120^{\circ} \mathrm{C}, 30 \mathrm{~min}$ TM<smiles>[R]C(=O)N([R])C=Cc1ccc(F)cc1</smiles><smiles>[R]C(C)C</smiles>

$\mathrm{Pd}^{0}$

Amide styrylation product<smiles>[R]C(=O)N[18O]C=Cc1ccc(F)cc1</smiles>

Scheme 3. Dual catalyst for Amide styrylation reaction. 


\section{Procedure}

After careful screening reagents (molar ratio, amount of catalyst, solvent, $\mathrm{Me}_{2} \mathrm{~S}$ for dissolving CuI, temperature, time) used in experiments to optimize the reaction conditions, the best condition found was one equivalent of amides and one equivalent of styryltrifluoroborates. The reaction scale was $0.5 \mathrm{mmol}$. After purging with argon to remove air, two microwave reaction flasks with magnetic stirrer bar in each were prepared. Flask 1 was loaded with $0.5 \mathrm{mmol}$ of potassium styryltrifluoroborates (90\% pure), $2 \mathrm{~mol} \%$ of $\mathrm{PdCl}_{2}\left(\mathrm{~d}^{\mathrm{t}} \mathrm{bpf}\right.$ ), and 2 equiv. of anhydrous $\mathrm{K}_{2} \mathrm{CO}_{3}$. The mixture was then capped and again purged with argon followed by adding $2 \mathrm{ml}$ of dry 1,4-dioxane under argon atmosphere and allowed to stir for $30 \mathrm{~min}$ at room temperature. Flask 2 was similarly loaded with $0.5 \mathrm{mmol}$ of amide, $100 \mathrm{~mol} \%$ of CuI catalyst, and 2 equiv. of $\mathrm{K}_{2} \mathrm{CO}_{3}$ as base. Then flask was capped and flushed with argon followed by the addition of $0.5 \mathrm{ml}$ of $\mathrm{Me}_{2} \mathrm{~S}$ and $2 \mathrm{ml}$ of 1,4-dioxane. The mixture was then allowed to stir for 30 $\mathrm{min}$ at room temperature. This 30 -min stirring was necessary before transferring the $\mathrm{Cu}$-species into $\mathrm{Pd}$-species. The solution of $\mathrm{Cu}$ complex was then added to the Pd complex solution by using cannula. After microwave irradiation, the crude reaction product was subjected to standard extraction with $100 \mathrm{ml}$ of diethyl ether, $50 \mathrm{ml}$ of brine solution, and $25 \mathrm{ml}$ of ammonium chloride. The separated organic layer was dried over anhydrous $\mathrm{Na}_{2} \mathrm{SO}_{4}$ and again filtered through celite twice to remove unwanted impurities. The filtrate was then evaporated by using rotary evaporator and the concentrated product was allowed to dry for overnight under vacuum pump for the removal of the solvents completely.

Formation of cross-coupling product $3 \mathrm{a}$ is the representative one. Flask 1 was loaded with $126 \mathrm{mg}(0.5 \mathrm{mmol})$ of potassium trans-2-(4-fluorophenyl)-vinyltrifluoroborates (90\% pure), $6.5 \mathrm{mg}$ ( $2 \mathrm{~mol} \%)$ of $\mathrm{PdCl}_{2}\left(\mathrm{~d}^{\mathrm{t} b p f}\right)$, and $138.21 \mathrm{mg}(2$ equiv.) of anhydrous $\mathrm{K}_{2} \mathrm{CO}_{3}$. The mixture was then capped and again purged with argon. Argon flashed flask was then loaded with $2 \mathrm{ml}$ of 1,4-dioxane under inert atmosphere and allowed to stir for $30 \mathrm{~min}$ at room temperature. Flask 2 was similarly loaded with $65.0 \mathrm{mg}(0.5 \mathrm{mmol})$ of $\mathrm{N}$-methyltrifluoroacetamide, $95.22 \mathrm{mg}$ (100 mol\%) of CuI catalyst and $138.21 \mathrm{mg}$ (2 equiv.) of $\mathrm{K}_{2} \mathrm{CO}_{3}$ as base. Then flask was capped and flushed with argon followed by the addition of $0.5 \mathrm{ml}$ of $\mathrm{Me}_{2} \mathrm{~S}$ and $2 \mathrm{ml}$ of 1,4-dioxane. The mixture then was allowed to stir for 30 min at room temperature. The solution of $\mathrm{Cu}$-complex was then added to the Pd-complex solution by using cannula. The resulting mixture was microwaved at $120^{\circ} \mathrm{C}$ for $30 \mathrm{~min} .{ }^{1} \mathrm{H}$ NMR (Acetone- $\mathrm{d}_{6}, 400 \mathrm{MHz}$ ): $\delta$ (ppm): 3a, $7.57-7.12$ (m, $4 \mathrm{H}), 7.37(\mathrm{~d}, \mathrm{~J}=16.0 \mathrm{~Hz}, 1 \mathrm{H}), 6.19(\mathrm{~d}, \mathrm{~J}=16.0 \mathrm{~Hz}, 1 \mathrm{H}), 3.60(\mathrm{~s}, 3 \mathrm{H}) ; 3 \mathrm{~b}, 7.42$ - $6.85(\mathrm{~m}, 4 \mathrm{H}), 7.24(\mathrm{~d}, \mathrm{~J}=15.0 \mathrm{~Hz}, 1 \mathrm{H}), 6.03(\mathrm{~d}, \mathrm{~J}=16.0 \mathrm{~Hz}, 1 \mathrm{H}), 2.92(\mathrm{~s}, 3 \mathrm{H})$; $3 c, 7.38-6.93(\mathrm{~m}, 9 \mathrm{H}), 7.22(\mathrm{~d}, \mathrm{~J}=16.0 \mathrm{~Hz}, 1 \mathrm{H}), 6.04(\mathrm{~d}, \mathrm{~J}=16.0 \mathrm{~Hz}, 1 \mathrm{H}), 1.93$ (s, 3H); 3d, $7.54-7.12(\mathrm{~m}, 8 \mathrm{H}), 7.40(\mathrm{~d}, \mathrm{~J}=16.0 \mathrm{~Hz}, 1 \mathrm{H}), 6.20(\mathrm{~d}, \mathrm{~J}=16.0 \mathrm{~Hz}$, $1 \mathrm{H}), 2.27(\mathrm{~s}, 3 \mathrm{H}), 2.10(\mathrm{~s}, 3 \mathrm{H}) ; 3 \mathrm{e}, 7.59(\mathrm{~d}, \mathrm{~J}=16.0 \mathrm{~Hz}, 1 \mathrm{H}), 7.58-7.13(\mathrm{~m}, 9 \mathrm{H})$, $7.38(\mathrm{~d}, \mathrm{~J}=16.0 \mathrm{~Hz}, 1 \mathrm{H}), 6.77(\mathrm{~d}, \mathrm{~J}=16.0 \mathrm{~Hz}, 1 \mathrm{H}), 6.22(\mathrm{~d}, \mathrm{~J}=16.0 \mathrm{~Hz}, 1 \mathrm{H}), 3.60$ (s, 3H); 3f, $7.41-6.99(\mathrm{~m}, 4 \mathrm{H}), 7.19(\mathrm{~J}=16.0 \mathrm{~Hz}, 1 \mathrm{H}), 6.19(\mathrm{~d}, \mathrm{~J}=16.0 \mathrm{~Hz}), 2.71$ 
(s, 3H), $2.32(\mathrm{~s}, 3 \mathrm{H}), 1.16(\mathrm{~s}, 9 \mathrm{H}) ; 3 \mathrm{~g}, 7.53-6.92(\mathrm{~m}, 9 \mathrm{H}), 7.40(\mathrm{~d}, \mathrm{~J}=16.0 \mathrm{~Hz}$, $1 \mathrm{H}), 6.19(\mathrm{~d}, \mathrm{~J}=176.0 \mathrm{~Hz}, 1 \mathrm{H}), 2.32(\mathrm{~s}, 3 \mathrm{H}), 2.07$ (s, 3H); 3h, $7.42-6.91(\mathrm{~m}, 8 \mathrm{H})$, $7.39(\mathrm{~d}, \mathrm{~J}=16.0 \mathrm{~Hz}, 1 \mathrm{H}), 6.18(\mathrm{~d}, \mathrm{~J}=1 \mathrm{H}), 2.33(\mathrm{~s}, 2 \times 3 \mathrm{H}), 2.07(\mathrm{~s}, 3 \mathrm{H})$.

\section{Acknowledgements}

Wejdan Shaban gratefully acknowledges the financial support from Saudi Arabian cultural mission to the US (SACM) for her graduate study at Tennessee State University.

\section{References}

[1] Wolfe, J.P., Wagaw, S. and Buchwald, S.L. (1996) An Improved Catalyst System for Aromatic Carbon-Nitrogen Bond Formation: The Possible Involvement of Bis (Phosphine) Palladium Complexes as Key Intermediates. Journal of the American Chemical Society, 118, 7215-7216. https://doi.org/10.1021/ja9608306

[2] Driverand, M.S. and Hartwig, J.F. (1996) A Second-Generation Catalyst for Aryl Halide Amination: Mixed Secondary Amines from Aryl Halides and Primary Amines Catalyzed by (DPPF)PdCl ${ }_{2}$. Journal of the American Chemical Society, 118 , 7217-7218. https://doi.org/10.1021/ja960937t

[3] Hamannand, B.C. and Hartwig, J.F. (1998) Systematic Variation of Bidentate Ligands Used in Aryl Halide Amination. Unexpected Effects of Steric, Electronic, and Geometric Perturbations. Journal of the American Chemical Society, 120, 3694 3703. https://doi.org/10.1021/ja9721881

[4] Guram, A.S. and Buchwald, S.L. (1994) Palladium-Catalyzed Aromatic Aminations with in Situ Generated Aminostannanes. Journal of the American Chemical Society, 116, 7901-7902. https://doi.org/10.1021/ja00096a059

[5] Wolfe, J.P., Wagaw, S., Marcoux, J.F. and Buchwald, S.L. (1998) Rational Development of Practical Catalysts for Aromatic Carbon-Nitrogen Bond Formation. Accounts of Chemical Research, 31, 805-818. https://doi.org/10.1021/ar9600650

[6] Muci, A.R. and Buchwald, S.L. (2002) Cross-Coupling Reactions-A Practical Guide. Topics in Current Chemistry, 219, 131.

https://doi.org/10.1007/3-540-45313-X_5

[7] Surry, D.S. and Buchwald, S.L. (2008) Biaryl Phosphane Ligands in Palladium-Catalyzed Amination. Angewandte Chemie International Edition, 47, 6338. https://doi.org/10.1002/anie.200800497

[8] Yin, J. and Buchwald, S.L. (2002) Pd-Catalyzed Intermolecular Amidation of Aryl Halides: The Discovery That Xantphos Can Be Trans-Chelating in a Palladium Complex. Journal of the American Chemical Society, 124, 6043-6048. https://doi.org/10.1021/ja012610k

[9] Jiang, L., Job, G.E., Klapars, A. and Buchwald, S.L. (2003) Copper-Catalyzed Coupling of Amides and Carbamates with Vinyl Halides. Organic Letters, 5, $3667-$ 3669. https://doi.org/10.1021/ol035355c

[10] Hartwig, J.F., Kawatsura, M., Hauck, S.L., Shaughnessy, K.H. and Alcazar-Roman, L.M. (1999) Room-Temperature Palladium-Catalyzed Amination of Aryl Bromides and Chlorides and Extended Scope of Aromatic C-N Bond Formation with a Commercial Ligand. Journal of Organic Chemistry, 64, 5575-5580. https://doi.org/10.1021/jo990408i

[11] Belfield, A.J. and Brown, G.R. (1999) Recent Synthetic Advances in the Nucleophilic 
Amination of Benzenes. Tetrahedron Letters, 55, 11399-11428. https://doi.org/10.1016/S0040-4020(99)00668-7

[12] Wang, Z., Skerlj, R.T. and Bridger, G.J. (1999) Regioselective Synthesis of Aryl Hydrazides by Palladium-Catalyzed Coupling of T-Butylcarbazate with Substituted Aryl Bromides. Tetrahedron Letters, 40, 3543-3546. https://doi.org/10.1016/S0040-4039(99)00561-4

[13] Arterburn, J.B., Rao, K.V., Ramdas, R. and Dible, B.R. (1999) Selective RheniumCatalyzed Oxidation of Secondary Alcohols with Methyl Sulfoxide in the Presence of Ethylene Glycol, a Convenient One-Pot Synthesis of Ketals. Organic Letters, 1, 769-771. https://doi.org/10.1021/ol990755e

[14] Fors, B.P. and Buchwald, S.L. (2009) Pd-Catalyzed Conversion of Aryl Chlorides, Triflates, and Nonaflates to Nitroaromatics. Journal of the American Chemical Society, 131, 12898-12899. https://doi.org/10.1021/ja905768k

[15] Saito, S. and Koizumi, Y. (2005) Copper-Catalyzed Coupling of Aryl Halides and Nitrite Salts: A Mild Ullmann-Type Synthesis of Aromatic Nitro Compounds. Tetrahedron Letters, 46, 4715-4717. https://doi.org/10.1016/j.tetlet.2005.05.033

[16] Al-Masum, M., Saleh, N. and Islam, T. (2013) A Novel Route to Organonitrites by Pd-Catalyzed Cross-Coupling of Sodium Nitrite and Potassium Organotrifluoroborates. Tetrahedron Letters, 54, 1141-1144. https://doi.org/10.1016/j.tetlet.2012.12.047

[17] Al-Masum, M. and Livinghouse, T. (1999) Pd(0)-Cu(I) Cocatlyzed Phosphorylation of Methylphenylphosphine-Borane with Aryl Halides and Aryl Nonaflateste. Tetrahedron Letters, 40, 7731-7734. https://doi.org/10.1016/S0040-4039(99)01636-6

[18] Amamoto, Y., Takada, S. and Miyaura, N. (2006) $\gamma$-Selective Cross-Coupling of Potassium Allyltrifluoroborates with Aryl and 1-Alkenyl Bromides Catalyzed by a $\mathrm{Pd}(\mathrm{OAc})_{2}$ /D-t-BPF Complex. Chemistry Letters, 35, 704.

https://doi.org/10.1246/cl.2006.704

[19] Al-Masum, M. and Alam, S. (2009) Remarkable Regioselectivity in Microwave Enhanced Palladium Catalyzed Allylation Reaction Involving Allyltrifluoroborates and Aryl Halides. Tetrahedron Letters, 50, 5201-5204. https://doi.org/10.1016/j.tetlet.2009.06.134

[20] Al-Masum, M. and Liu, K.-Y. (2011) A New Organic Transformation by Introducing Crotyl $\backslash$ Allyltrifluoroborates in Cross-Coupling Reaction with Aroyl Chlorides. Tetrahedron Letters, 52, 5090-5093. https://doi.org/10.1016/j.tetlet.2011.07.107

[21] Grasa, G.A. and Colacot, T.J. (2007) a-Arylation of Ketones Using Highly Active, Air-Stable (DtBPF)PdX $2(\mathrm{X}=\mathrm{Cl}, \mathrm{Br})$ Catalysts. Organic Letters, 9, 5489-5492.

[22] Mann, G., Shelby, Q., Roy, A.H. and Hartwig, J.F. (2003) Electronic and Steric Effects on the Reductive Elimination of Diaryl Ethers from Palladium(II). Organometallics, 22, 2775-2789. https://doi.org/10.1021/om030230x

[23] Elsagir, A.R., Gassner, F., Gorls, H. and Dinjus, E. (2000) Bidentate Ferrocenyl Phosphines and Their Palladium(II)Dichloride Complexes-X-Ray Structural and NMR Spectroscopic Investigations and First Results of Their Characteristics in the Pd-Catalysed Cooligomerisation of 1,3-Butadiene with $\mathrm{CO}_{2}$. Journal of Organometallic Chemistry, 597, 139-145. https://doi.org/10.1016/S0022-328X(99)00670-1

[24] Bianchini, C., Meli, A., Overhauser, W., Parisel, S., Passaglia, E., Ciardelli, F., Gusev, O.V., Kal'sin, A.M. and Vologdin, N.V. (2005) Ethylene Carbonylation in Methanol and in Aqueous Media by Palladium(II) Catalysts Modified with 1,1'-Bis(Dialkylphosphino) Ferrocenes. Organometallics, 24, 1018-1030. 
https://doi.org/10.1021/om049109w

[25] Oliverira, R.A., Silva, R.O. and Molander, G.A. (2009) ${ }^{1} \mathrm{H},{ }^{13} \mathrm{C},{ }^{19} \mathrm{~F}$ and ${ }^{11} \mathrm{~B}$ NMR Spectral Reference Data of Some Potassium Organotrifluoroborates. Magnetic Resonance in Chemistry, 47, 873-878. https://doi.org/10.1002/mrc.2467

[26] Dolbier, W.R. (2009) Guide to Fluorine NMR for organic Chemist. John Wiley \& Sons, Inc., Hoboken, 213 p. https://doi.org/10.1002/9780470483404

Submit or recommend next manuscript to SCIRP and we will provide best service for you:

Accepting pre-submission inquiries through Email, Facebook, LinkedIn, Twitter, etc. A wide selection of journals (inclusive of 9 subjects, more than 200 journals)

Providing 24-hour high-quality service

User-friendly online submission system

Fair and swift peer-review system

Efficient typesetting and proofreading procedure

Display of the result of downloads and visits, as well as the number of cited articles Maximum dissemination of your research work

Submit your manuscript at: http://papersubmission.scirp.org/

Or contact ijoc@scirp.org 